\title{
REDUCING AGENCY COSTS BY SELECTING AN APPROPRIATE SYSTEM OF CORPORATE GOVERNANCE
}

\author{
Ljiljana Maurovića, Tea Hasićb
}

${ }^{\text {a } F u l l ~ P r o f e s s o r, ~ P h . D, ~ J u r a j ~ D o b r i l a ~ U n i v e r s i t y ~ o f ~ P u l a, ~ F a c u l t y ~ o f ~ E c o n o m i c s ~ a n d ~ T o u r i s m ~ “ D r . ~ M i j o ~ M i r k o v i c ́ ", ~ P r e r a d o v i c ́ e v a ~}$ 1/1, Pula, Croatia, ljmaurov@efpu.hr.

${ }^{b}$ Research Assistant and PhD Candidate, University of Pula, Faculty of Economics and Tourism "Dr. Mijo Mirković", Preradovićeva 1/1, Pula, Croatia, thasic@unipu.hr.

\section{ARTICLE INFO}

Keywords:

- Principal-Agent Problem,

- One-Tier and Two-Tier System of

Corporate Governance,

- Directors' liability

\section{ABSTRACT}

This paper analyzes the Principal-Agent Problem in Corporate Governance.

Focus is on the question: One-Tier or Two-Tier system of Corporate Governance - which one is more effective in reducing Agency Costs?

The authors analyze provisions regulating corporate governance in different legal systems, and therefore, they conclude: It should be prescribed by Codes of Corporate Governance that system of corporete governance applied in particular company shall depend on its shareholding structure. Consequently, significant indication for potential investors to not invest in the company, would exist if the best practice of corperate governance (including the system of Corporate Governance recommended by CCG) is not applied.

Reference to this paper should be made as follows: Maurović Lj, Hasić T,. 2013. Reducing agency costs by selecting an appropriate system of corporate governance, Ekonomska istraživanja - Economic Research Special Issue 2013 


\section{INTRODUCTION}

\section{A. Theoretical Background}

\section{i. Principal-Agent Problem vs. Conflict of Interest in Corporate Governance (Principal-Agent Relationship in Economic vs. in Legal Sense)}

Agency Problem or Principal-Agent Problem is the term which has been used amongst economic theoreticians, as a synonym for "the conflict of interest in corporate governance" ${ }^{\prime \prime}$, since 1976, when Jensen and Meckling, in their capital work "Theory of The Firm: Managerial Behaviour, Agency Costs and Ownership structure ${ }^{\prime 2}$ defined the concept of Agency Costs to show its relationship to the "separation of ownership and control issue" - immanent for joint stock companies (corporations).

Jensen and Meckling define shareholders-management relationship as a typical PrincipalAgent relationship ${ }^{3}$ (hereinafter: P-A relationship). Namely, most economists define as a P-A relationship, entire spectrum of relationships (no matter whether they are contractual or not) where welfare of one person (or one group of persons) depends on activities undertaken by another person (or another group of persons). ${ }^{4}$ Directors should be professionals, educated and qualified to run a business, and therefore, they should ensure efficient governance. Accordingly, the income of investors (shareholders) directly depends on directors who govern the company's business and therefore, relation between directors and shareholders is a pure P-A relationship, but only in economic sense (as we will explain later in this text).

Moreover, according to economic theoreticians, The Principal-Agent problem in corporate governance may appear in, at least, three forms, or, on three levels: ${ }^{5}$

a) Between directors (as agents) and shareholders (as principals)

b) Between majority or controlling shareholders (as agents) and minority or non-controlling shareholders (as principals)

c) Between the company, or more specific - between the group of person who are in control of the company - i.e. directors or majority/controlling shareholders (as agents) and stakeholders who do not participate directly in corporate governance, although the achievement of their personal interest depends (more or less directly) on company's business achievement (as principals). For example, stakeholders who do not participate directly in corporate governance, but do have a direct interest for "good corporate governance", would be: employees and creditors of the company, consumers of the company's products, local community etc.

We have already emphasized that terms "agent" and "principal" - as used by economic theoreticians, do not stand for terms "agent" and "principal" in legal sense. Namely, in legal sense,

\footnotetext{
1 A phrase used amongst legal theoreticians and practitioners

${ }^{2}$ Michael C. Jensen and Wiliam H. Meckling, "Theory of The Firm: Managerial Behaviour, Agency Costs and Ownership Structure,"Journal of Financial Economics 3 (1976): 305 - 360, available at: http://ssrn.com/abstract=94043

${ }^{3}$ Jensen and Meckling, "Theory of The Firm," 6; John Armour, Henry Hansmann and ReinierKraakman, "Agency Problems, Legal Strategies and Enforcement,"Harvard - John M. Olin Center for Law, Economics and Business, Discussion Paper, 644 (2009): 2-4, available at: http://www.law.harvard.edu/programs/olin_center/

"Jensen and Meckling, "Theory of The Firm," 5; Armour, Hansmann and Kraakman, "Agency Problems," 2.

${ }^{5}$ See: Paul L. Davies, "The Board of Directors: Composition, Structure, Duties and Powers" (paper presented at Conference on Company Law Reform in OECD Countries: A Comparative Outlook of Current Trends, Stockhlom, Sweeden, December 7-8, 2000): 2, available at: http://www.oecd.org/daf/ca/corporategovernanceprinciples/1857291.pdf
} 
agents are persons who act on behalf of another person - a principal. Consequently, the term agent - in legal sense, does not determine every person whose actions create benefit to another person, as in economic sense. ${ }^{6}$ This indicates that, in legal sense, in first two mentioned forms of Agency Problem, the principal would be the company, whilst agents would be directors - as they are legally entitled to act on behalf of the company (not on behalf of shareholders as a class). On an exceptional basis, in situations where the Shareholders' Meeting (as the company's body) is entitled to take individual decisions on behalf of the company, shareholders who exercised their voting rights may be considered as agents because they took a decision in the name of the company - a principal. Finally, we conclude that in the third form of Agency Problem, the principal agent relationship (in legal sense) does not exist at all. Namely, the company is not entitled to act on behalf of any potential principal as mentioned before - employees, creditors, consumers, local community etc., nor vice versa.

The mere essence of Corporate Governance Law, even Company Law in general, is to set provisions for struggling against the conflict of interest between different interest groups who participate in corporate governance, i.e. between directors and shareholders - which includes majority and minority shareholders. Therefore, the core provisions of Company Law are set to reduce, what economists would refer to as, the first and second form of Principal-Agent Problem.? The conflict of interests always exists between the company itself and stakeholders who do not participate directly in corporate governance, regardless of the fact whether directors or majority shareholders are in control of the company. However, legal provisions aimed to reduce the third form of Agency Problem do not form a part of Company Law, so these provisions are not going to be examined in this paper.

\section{ii. Agency Costs}

"Agency Cost" is the term that indicates the amount of benefits which "agents" (i.e. directors or majority/controlling shareholders) usurp for themselves instead for the company. It can also indicate the lack of performance quality - when "agents" did not usurp benefits for themselves, but they have failed to achieve the agreed or the expected goals. Moreover, to get the total amount of Agency Costs, we also have to take into account the amount of money used for undertaking different kind of measures for struggling against The Agency Problem. Accordingly, it would be advisable to apply those measures which do not provoke unnecessary costs. We should also notice that Agency Costs grow if there is more than one principal. Namely, if there are numerous principals, they usually have different interests, so they are less likely to act in concern and to control "agents" adequately. Moreover, Agency Costs are expected to grow if agents' tasks are complicated. Hence, the more complicated the task is, the harder it is to set the adequate control. Therefore, additional supervising methods should be applied, what will provoke additional costs. Nevertheless, even if additional supervising methods are applied, "agents" are still in a way better position to constrain information from principals and regulatory bodies, especially when their task is extremely complicated. ${ }^{8}$

\footnotetext{
${ }^{6}$ See: Armour, Hansmann and Kraakman, "Agency Problems," 2.

7 See: Armour, Hansmannand Kraakman, "Agency Problems," 2.

${ }^{8}$ For definition of "Agency Costs" see: Jensen and Meckling, "Theory of The Firm," 5 - 6;Armour, Hansmann and Kraakman, "Agency Problems," 2.
} 


\section{B. Main Thesis}

\section{i. There is a Correlation between Shareholding Structure and The Form (The Level) of Prin- cipal-Agent Problem}

If the shareholding structure is dispersed, the first form of Agency Problem will prevail. On the other hand, if the shareholding structure is concentrated, the second form of Agency Problem will prevail. ${ }^{9}$ Namely, in companies with dispersed shareholding structure, shareholders do not have (effective) control over directors. Therefore, uncontrolled position enables and motivates directors to act opportunistically.

Furthermore, in companies where one or a few persons hold $25 \%$ or more shares, they have control over the company, so the Agency Problem is being transmitted from directors vs. shareholders relationship, to controlling vs. non-controlling shareholders relationship. The respective problem escalates if one or few shareholders who act in concern hold more than $50 \%$ of shares. Accordingly, always when simple majority of votes is required, they are able to take independently (without consent of other shareholders) any decision on behalf of the company. Moreover, the second form of Agency Problem culminates if majority shareholder holds more than $75 \%$ of shares; hence it enables him/her to take decisions on behalf of the company, even if qualified majority of $3 / 4$ votes is required.

Although in every joint-stock company first or second form of Agency Problem prevails -depending on the structure of shareholders, it does not mean that these two problems exclude one another. ${ }^{10}$ Namely, even if controlling shareholder is able to influence directors, the latter still undertake so called "operative" or "day to day" business - where they get a "first-hand information". Directors are usually able to suppress informations from controlling shareholder and to use them in their own interest, instead in the interest of the company. The co-existence of first and second form of Agency Problem is especially emphasized in companies where controlling shareholder does exist, but does not hold more than $50 \%$ of shares - he is a controlling shareholder, but nevertheless, he is not a majority shareholder. Holding between $25-50 \%$ of shares enables him to block some decisions - for example, the ones for whose entering into force qualified majority of $3 / 4$ votes is required, but still does not enable him to take decisions on behalf of the company without consent of other shareholders. In a respective situation, the controlling shareholder is not able to control directors efficiently. Therefore, he is able to oppress non-controlling shareholders, while directors are still able to (in a way) oppress shareholders as a class (what includes both, controlling and non-controlling). Consequently, we may conclude that here the first and second form of Agency Problem co-exist.

Moreover, in companies with dispersed shareholding structure, directors have control over the company, because no other interest group is strong enough to impact on their decisions and to control them efficiently. Although, shareholders may agree to act in concern in order to control directors more efficiently, by agreeing to act in concern they would establish "a fertile soil" for growth of the second type of Agency Problem i.e., between shareholders who agreed to act in concern (as agents) and shareholders who did not assent on such agreement (as principals). Consequently, we may conclude that this would be another situation where the first and the second form of Agency Problem co-exist.

\footnotetext{
9 See:Armour, Hansmann andKraakman, "Agency Problems," 16; Davies, “The Board of Directors," 3.

${ }^{10}$ For contrary opinion see: Davies, "The Board of Directors," 2.
} 


\section{ii. Appropriate System of Corporate Governance May Reduce The Conflict of Interest be- tween Stakeholders}

Every legislator has set the corporate governance rules in order to combat or, at least, to reduce the conflict of interest (i.e. to combat or to reduce the Agency Problem in economic sense) which dominates in the most companies registered in its country.

Therefore, in Anglo-Saxon Legal Systems, where the first type of Agency Problem prevails, because in major proportion of companies the shareholding structure is dispersed, - rules of law are set to regulate the conduct of directors, in addition to constrain them to act in their personal interest. Those rules form the set of rules known as One-Tier or Single Board System of Corporate Governance.

On the other hand, in Continental Legal Systems, where in major proportion of companies the structure of shareholding is concentrated, the second type of Agency Problem prevails. Accordingly, the legislator's aim is to constrain the power of controlling (especially majority) shareholder. Rules set to constrain the power of majority/controlling shareholder, form the system of corporate governance known as Two-Tier or Dual Board System.

It is impossible to provide the same set of rules regulating the relation between directors and shareholders (i.e. it is impossible to provide the same system of corporate governance) which would be appropriate for reducing the first and second type of Agency Problem. ${ }^{11}$ Therefore, legislators provide the specific set of rules in order to empower non-controlling (especially minority) shareholders in exercising their rights. ${ }^{12}$ This area of Company law is known as: minority shareholders' rights and it plays important role, especially in continental countries, where minority shareholders may easily be oppressed by majority shareholder.

In this paper, authors are not going to analyze measures for protecting and enhancing minority shareholders' rights. The focus would be on rules regulating relationship between directors and shareholders - for example, on rules which regulate division of powers between Board of Directors and General Meeting of Shareholders; shareholders' right to impact on directors' decisions; shareholders' rights to elect and to remove directors etc. Accordingly, those rules may be set to constrain the power of directors (as they are in One-Tier System) or to constrain the power of majority shareholder (as they are in Two-Tier System), but nohow to constrain the power of both of them. This is the main reason why in countries where dispersed shareholding traditionally dominates, legislator provides One-Tier System, while in countries where concentrated shareholding traditionally dominates, legislator provides Two-Tier System as a mandatory system. This has been restrained under the influence of Regulation on the Statute for a European Company (SE), ${ }^{13}$ where it is prescribed that in every EU member state, the founders must have the right of choice between One-Tier and Two-Tier System when they are founding SE. This provision does not take

\footnotetext{
${ }^{11}$ For example, rules of law regulating competencies or election and revocation of directors, may be appropriate to reduce solely first or second type of Agency Problem and nohow both of them. See: Davies, "The Board of Directors," 2.

12 If in particular company first and second type of Agency Problem co-exist, it is recommended to use the set of rules (the system of corporate governance) appropriate for reducing the Agency Problem between directors and shareholders, whilst measures for protecting and enhancing minority shareholders' rights would be appropriate for reducing the Agency Problem between majority and minority shareholders. See: Davies, "The Board of Directors," 2, 11, 14. ; Armour, Hansmann and Kraakman, "Agency Problems," 16.

${ }^{13}$ Council Regulation (EC) No 2157/2001 of 8 October 2001 on the Statute for a European company (SE), OJ L294, $10 / 11 / 2001$
} 
into account joint-stock companies registered in EU member states under the domestic law, so if under the domestic company law One-Tier or Two-Tier System is still mandatory system, founders of those kind of companies are obliged to apply it. Under the influence of respective Regulation, several member states (as we will see in next sub-chapter) have introduced the right of choice between One-Tier and Two-Tier System under their national Company Law Acts in order to ensure the right of choice for those who decide to found the company in accordance with national law. We believe that EU legislator have decided to confer the right of choice between One-Tier and TwoTier System upon the founders of the SE in order to make a compromise between Anglo-Saxon and Continental Company law rules. It is a notorious fact (at least between legal practitioners and theoreticians) that compromise-solutions are, unfortunately, very often inappropriate solutions. In this paper we will try to explain why we believe that it is inappropriate to confer the right of choice between One-Tier and Two-Tier System upon the members of the company, and moreover, we will try to bring out solution which may (at least we believe so) be appropriate to reduce the respective problem.

\section{The Problem}

If legislator provides only One-Tier System (Belgium, Cyprus, Denmark, Greece, Ireland, Luxemburg, Malta, Sweden, Spain, Switzerland) or only Two-Tier System (Germany, Austria, Czech Republic, Hungary, Poland, Slovakia), the problem occurs. Namely, legislator provides a system of corporate governance which is more effective in reducing the type of Agency Problem which prevails in major proportion of companies i.e., One-Tier System - to combat Agency Problem between directors and shareholders (where the shareholding structure is traditionally dispersed); and TwoTier System - to combat Agency Problem between controlling and non-controlling shareholders (where the shareholding structure is traditionally concentrated)..$^{14}$ In every country, regardless of the fact whether the dispersed or concentrated structure of shareholders prevails, it is possible to form a company with opposite structure of shareholders. For example, it is possible to form a company with majority shareholder in Great Britain, just as it is possible to found a company with dispersed shareholders in Germany. ${ }^{15}$ If founders of the company are not entitled to select a system of corporate governance which is appropriate for their company, Agency Problem will multiply. For example, Agency Problem will multiply if One-Tier System is ex lege applied in a company with concentrated shareholders' structure, or if Two-Tier System is ex lege applied in a company with dispersed shareholders.

In some countries (Croatia, France, Italy, Slovenia, FYR Macedonia, Iceland, Lithuania, Netherlands, Portugal), founders of company are entitled to select the system of corporate governance. Although it seems to be a reasonable measure at the first sight, we conclude that conferring a right of choice upon the founders of the company is a counterproductive measure which is likely to multiply Agency Costs. For example, if under the articles of association, under the influence of majority shareholder, the One-Tier System is being introduced, although the structure of share-

\footnotetext{
${ }^{14}$ See: Davies, "The Board of Directors," 3; Armour, Hansmann and Kraakman, "Agency Problems," 16.; LjiljanaMaurović, MarliGonanBožac and Sabina Lacmanović,"The One-Tier System on Corporate Governance - Croatian Practice,"Economic Research22 (2009): 9, available at: http://hrcak.srce.hr/38201

${ }^{15}$ In Anglo-Saxon countries, especially UK and USA, the proportion of companies with concentrated shareholding is being increased as a direct consequence of institutional shareholding growth. On the other side, for example in Croatia, where shareholding structure used to be extremely concentrated, recently is notable that number of companies with concentrated shareholding structure is being decreased - as The Republic of Croatia started to sell the blocks of shares which were in the State's portfolio.
} 
holders is extremely concentrated, the majority shareholder would be able to control a decision making process in Shareholders' Meetings, and moreover, he would be able to influence directly on directors' decisions, hence, in One-Tier System directors are subordinated to General Meeting of Shareholders. Accordingly, majority shareholder would be able to use the company to achieve his personal interest, while no one would be able to oppose him adequately.

\section{The Purpose of the Paper}

The purpose of this paper is to provide the answer on the question highlighted in the abstract: One-Tier or Two-Tier System of Corporate Governance - which one is more effective in reducing Agency Costs?

Moreover, this paper shall bring solution for solving the problem described in previous chapter. Therefore, the authors' aim is to suggest the legal framework which will provide that:

a) The right of choice between systems of corporate governance is conferred upon the founders of the company, BUT

b) The respective choice should be made in accordance with certain "parameters".

\section{E. Methodology}

In this paper, in order to detect the most appropriate system of corporate governance for reducing Agency Costs, authors analyze different legal systems and their provisions regulating the following:

a) Division of powers between directors and shareholders

b) Election and revocation of directors

Furthermore, in chapter 2.3., authors analyze provisions regulating directors' liability. Hence, those provisions (and their judicial enforcement) may reduce Agency Costs significantly, no matter whether One-Tier or Two-Tier system is applied.

\section{RULES OF LAW REGULATING THE RELATIONSHIP BETWEEN DIRECTORS AND SHAREHOLDERS}

\section{A. Division of Powers between Directors and Shareholders}

In Anglo-Saxon countries, shareholders are traditionally believed to be the owners of the company. ${ }^{16}$ Therefore, in legal practice and theory dominates the opinion that the right to govern a company is initially conferred upon the shareholders (as the right of ownership is the highest right, which, amongst others, encompasses the right to govern). Nevertheless, as owners, shareholders are entitled to confer certain or all governing rights upon directors, who will then, accordingly, be obliged to run a business as their agents. Under The Companies Act (2006) $)^{17}$ division of powers between the Board of Directors and the General Meeting of Shareholders is not prescribed. It is just said that it's upon shareholders to decide, under the articles of association, which governing rights they will confer upon the Board of Directors.

\footnotetext{
${ }^{16}$ See: Paul L. Davies,Gower and Davies' Principles of Modern Company Law -ninth edition (London: Sweet \& Maxwell, 2012), 691-692; Stephen Girvin, Sandra Frisby and Alastair Hudson, ed., Charlesworth's Company Law - 18th edition (London: Sweet and Maxwell, 1996), 505-508; For Case Law, see: North-West Transportation Co v Beatty (1887), Burland v Earle (1902), Goodfellow v Nelso Line (1912).

${ }^{17}$ Companies Act2006 (hereinafter: CA), available at: http://www.legislation.gov.uk/ukpga/2006/46/contents
} 
On the other hand, in Continental Law System countries, the Board of Directors and the General Meeting of Shareholders are said to be the equally important bodies of the company, hence, there is no hierarchy amongst them. Instead, under the Company Law provisions, the powers of those bodies are strictly divided, and therefore, they may not interfere with each other's area of competencies. Rules of law regulating division of powers between directors and shareholders are mandatory, and just in a few exceptional circumstances it is possible to set different provisions under the articles of association.

\section{i. Division of Powers between Directors and Shareholders in One-Tier System of Corporate Governance}

In One-Tier System of corporate governance, there is no rigid division of powers between Board of Directors and General Meeting of Shareholders. The most "liberal" system is in UK, where under The Companies Act shareholders are entitled to determine to which extent they are going to confer the governing rights upon the Board of Directors. Until the beginning of the twentieth century, legal theoreticians and practitioners believed that shareholders are entitled to interfere with Board's decisions even when decision is to be taken in area conferred upon Board. ${ }^{18}$ General Meeting of Shareholders was held to be the supreme body, entitled to give binding instructions to directors, who were assumed to be just shareholders' agents. ${ }^{19}$ Nevertheless, by the end of nineteenth century, courts begun to take a reversible approach. First it was introduced in Automatic Self-Cleaning Filter Syndicate Co $v$ Cuninghame $(1906)^{20}$, than it has been generally accepted since Quin \& Axtens v Salmon (1909)21, and finally clearly stated in Shaw \& Sons (Salford) Ltd $v$ Shaw (1935)22: "If powers of management are vested in the directors, they and they alone can exercise these powers. The only way in which the general body of the shareholders can control the exercise of the powers vested by the articles in the directors is by altering their articles, or, if opportunity arises under the articles by refusing to re-elect the directors of whose actions they disapprove".23

It seems interesting to notice that soon after courts had adopted this new approach, the legislator (in 1948) introduced a new provision under The Companies Act, which prescribed that shareholders are able to remove directors from the Board at any time by ordinary resolution. ${ }^{24} \mathrm{We}$ believe that courts have chosen the appropriate path when they stated that shareholders shall not interfere with the Board of Directors' decisions. Namely, directors are not agents of shareholders. Once they were given certain powers, under the articles of association, they are entitled to exercises those powers in good faith in the best interest of the company and no one is allowed to interfere with their decisions, including shareholders. On the other hand, if we consider that in Anglo-Saxon Countries dispersed shareholding traditionally dominates, we understand why the legislator decided to increase and to facilitate the right of shareholders to remove directors at the very same time when courts forbid unsatisfied shareholders to interfere with Board's decisions. The new case-law approach strenghtened the position of directors and decreased the power of shareholders who could hardly control directors even when they were able to interfere with

\footnotetext{
${ }^{18}$ Isle of Wight Railway v Tahourdin case - 1883, 25 Ch. D. 320. CA - as cited in Davies, Gower and Davies' Principles, 387

${ }^{19}$ Davies, Gower and Davies' Principles, 384

${ }^{20}$ Automatic Self-Cleaning Filter Syndicate Co v Cuninghame (1906, 2 Ch. 34, CA) - as cited in Davies,Gower and Davies' Principles, 387.

${ }^{21}$ Quin\&Axtens v Salmon (1909, 1 Ch. 311 CA) as cited in Davies, Gower and Davies' Principles, 388.

${ }^{22}$ Shaw \& Sons (Salford) Ltd v Shaw (1935, 2 K. B. 113, CA at 134) as cited in Davies, Gower and Davies' Principles, 388-389.

${ }^{23}$ Davies, Gower and Davies' Principles, 389

${ }^{24}$ Par. 168 CA
} 
Board's decisions. Shareholders were dispersed and, in most cases, unable to act in concern and to control directors adequately. The legislator has introduced the new removal right for shareholders, probably in order to constrain directors to act opportunistically.

What was introduced in the middle of the 20th Century, today still exists. The Companies Act still does not regulate the division of powers between the Board of Directors and General Meeting of Shareholders. It is on shareholders to decide, under the articles of association, what are the competencies of the Board and what are the competencies of Shareholder Meetings, but once they have decided so, they are not allowed to interfere with Board's decisions any more. If shareholders are not satisfied with directors, they can remove them in any time by ordinary resolution, and if they are not satisfied with the division of powers they can always alter the articles of association.

In USA, powers between the Board of Directors and the General Meeting of Shareholders are divided by the law, but those provisions are not mandatory. Therefore, under the articles of association, competencies may be transferred from one body to another. Nevertheless, shareholders rarely decide to use possibility to confer competencies from Board of Directors upon themselves. Namely, if General Meeting of Shareholders takes a certain decision, even when it just confirms a decision taken by the Board, it is not possible to call directors for liability any more, if it turns to be an inappropriate decision. ${ }^{25}$

In Continental countries which introduced One-Tier System as optional system of corporate governance, or One-Tier System is traditional system of governance - hence, shareholding structure is not concentrated (which is characteristic for Continental-Roman Legal System Countries - such as France, Spain, Italy...) powers between Board of Directors and General Meeting of Shareholders are divided by law and those provisions are (generally) binding, but, as we will see in next chapters, shareholders are entitled to elect directors and to remove them at any time without any particular reason. Therefore, we may conclude that de iure independent position of directors (hence, shareholders are not entitled to interfere with their decisions) is de facto reduced by strong removal rights owned by shareholders.

\section{ii. Division of Powers between Directors and Shareholders in Two-Tier System of Corporate Governance}

In legal systems where companies with concentrated shareholding traditionally dominate (such as in Continental-German Legal System Countries and in Japan), the powers between directors (Managing Board), Supervisory Board and General Meeting of Shareholders are strictly divided by mandatory company law provisions. Namely, if it would be possible to confer powers from directors upon General Meeting of Shareholders, the power of already over-powerful majority shareholder would be even more strengthened. ${ }^{26}$

In Germany, under the mandatory provisions of Aktiengesetz (hereinafter: AktG), ${ }^{27}$ competencies of Managing Board and General Meeting of Shareholders are strictly divided..$^{28}$ Neverthe-

\footnotetext{
${ }^{25}$ See: Davies, "The Board of Directors," 5.

${ }^{26}$ See: Davies, "The Board of Directors," 12.

${ }^{27}$ Aktiengesetz (Stock Corporation Act) of 6. September 1965, (Federal Legislative Journal I p. 1089), last amended by Art. 26 of the Act of 23. July 2013, (Federal Legislative Journal I p. 2586), available at: http://www.gesetze-im-internet.de/ bundesrecht/aktg/gesamt.pdf

${ }^{28} \$ \$ S 76$ and 119 AktC
} 
less, the case-law "invented" an "interesting" institute - Unwritten Competences of General Meeting of Shareholders (Case Holzmüller). ${ }^{29}$ In accordance with a respective case-law institute, Managing Board is obliged to ask for shareholders' approval when it is about to take a decision that might have enormous consequences on company as a whole (although, shareholders' approval is not prescribed neither by the law, nor by the articles of association). This case-law approach has been followed by several legal uncertainties, for example: whether a certain decision might have serious consequences on company as a whole or not, and who is entitled to decide so? We might say that this problem has been solved, since case-law introduced several criteria ${ }^{30}$ which should help the members of the Managing Board when they are deciding whether they are going to ask for shareholders' approval or not.

In Croatia, (same as in Germany, Austria, Slovenia ...) powers of Managing Board, Supervisory Board and General Meeting of Shareholders are strictly divided by the mandatory company law provisions. In Croatia, Austria and Slovenia, the institute of Unwritten competences of General Meeting of Shareholders has not been introduced. Nevertheless, under the Croatian Companies Act a new provision ${ }^{31}$ has been introduced under the influence of Holzmlüller-case. It provides that directors, in several situations, must ask for shareholders' approval before they take a decision, hence those decisions might affect company as a whole seriously.

\section{B. Election and Revocation of Directors}

From rules of law regulating election and revocation of directors, it is easy to conclude who (de iure) is in control over the company. If General Meeting of Shareholders is entitled to elect shareholders, and especially, if it is entitled to remove them from the Board at any time and without a particular reason (as it usually is One-Tier System), it means that shareholders possess a control over the company. Nevertheless, we must notice that legislator confers strong election and removal rights upon shareholders when there is a plenty of them and when they are dispersed which enables directors to control the company in practice, no matter how strong shareholders de iure are. We can conclude that, in order to constrain over-powerful directors, who may not be adequately controlled by numerous and dispersed shareholders, the legislator provides legal environment adequate to raise the strength of shareholders. Those set of rules usually may be found in One-Tier System of Corporate Governance, as we will see in following sub-chapter.

On the other hand, where the legislator's aim is to constrain the power of majority shareholders - in order to combat or, at least, to reduce their ability to impact on directors and thus, to decrease the conflict of interest between majority and minority shareholders -legislator does not confer strong election and removal rights upon shareholders. Usually, the Supervisory Board is entitled to elect directors and to remove them from the Board - but only if there is a sufficient reason. Therefore, we can conclude: where companies are being controlled by majority shareholders, legislator provides a legal environment adequate to ensure independent position of directors in order to reduce the ability of majority shareholder to impact on directors and induce them

\footnotetext{
${ }^{29}$ BGHZ 83, 122 ("Holzmüller”). More about "Holzmüller Case” see in: Marc Löbbe,"Corporate Groups: Competences of the shareholders' meeting and minority protection - the BGH's recent Gelatine and Macrotron cases redefine the Holzmüller doctrine," German Law Journal,5 (2004): 1058-1079, available at: http://www.germanlawjournal.com/pdfs/Vol05No09/ PDF_Vol_05_No_09_1057-1079_Private_Loebbe.pdf; LudgerSchultand Tobias Nikoleyczik, "Shareholder approval for corporate acquisitions - the Commerzbank/Dresdner Bank case," Corporate and M\&A Law Newsleter, September (2012): 35-36, available at: http://www.glns.de/fileadmin/user_upload/dokumente/IBA_M_A_Newsletter.pdf

${ }^{30}$ See: Cf. BGH ZIP 2004, 993 and BGH ZIP 2004, 1001. ("The Gelatine Cases")

${ }^{31}$ Par. 552 Croatian Companies Act
} 
to act in his personal interest. This should, consequently, reduce the conflict of interest between majority and minority shareholders. Such a legal environment may be found in a set of rules which form so called Two-Tier System of Corporate Governance.

\section{i. Election and Revocation of Directors in One-Tier System of Corporate Governance}

In the UK, under the Companies Act, it is only prescribed that founders of the company shall decide - under the articles of association, who will and under what kind of procedure elect the Board of Directors. Hence, although CA does not confer the right to elect directors upon the shareholders, it provides that shareholders are entitled to decide how directors shall be elected, therefore they may confer those right upon themselves or upon anybody else. As we have already explained in chapter 2.1.1., before 1948, Companies Act provided the same provision for removal rights - the founders of the company were entitled to decide, under the articles of association, who would be allowed to remove directors from the board. Hence, at the very same time, Courts have generally accepted the approach providing that General Meeting of Shareholders is not entitled to interfere with Board's decisions taken in accordance with competencies conferred (under The Articles of Association) upon the Board, as a consequence - the legislator decided to strengthen shareholders' position, conferring upon them the right to remove directors at any time, without a particular reason. That provision (par. $168 \mathrm{CA}$ ) is mandatory - therefore, removal rights may not be vested upon other body or other person, even if somebody else has elected the members of the Board. Consequently, in UK, even if directors are de iure entitled to take decisions independently - as they are not legally obliged to follow the shareholders' instructions, their independence is seriously reduced by par. 168 CA. Accordingly, if directors do not follow shareholders' instructions, they will not breach the law, therefore, they will not be liable for any possible harm, if they have acted in accordance with their due diligence. Nevertheless, it is expected that, in a respective scenario, shareholders would not be satisfied with director's performance; consequently, they will remove them from the Board.

As it has been already stated earlier in this work, in Croatia, founders of the company are entitled to choose whether they want to apply One-Tier or Two Tier-System. ${ }^{32}$ Founders are only able to decide, under the articles of association, whether they want to apply One-Tier or Two-Tier System, but once they have made a respective choice, they have almost "no free space" to regulate governance of the company as they would like to. Instead, they must follow The Companies Act rules - which are, in the area of corporate governance, generally mandatory - no matter whether under the articles of association One-Tier or Two-Tier System is applied.

Under Croatian Companies Act, ${ }^{33}$ when One-Tier System is applied, the members of the Board of Directors shall be elected on the General Meeting of Shareholders by the ordinary resolution. ${ }^{34}$ Nevertheless, in One-Tier System, the right to elect directors is not exclusively General Meetings' right. Namely, under the articles of association it may be prescribed that maximally one third of Board's members may be elected by certain ${ }^{35}$ shareholder(s). ${ }^{36}$ Moreover, in an exceptional

\footnotetext{
32 Par. 173/3 Croatian Companies Act

${ }^{33}$ Par. 272 c.Croatian Companies Act

${ }^{34}$ Under The Articles of Association, qualified majority of votes or special quorum may be prescribed

35 "Certain shareholder(s)" means: a) a shareholder identified by name and surname under The Articles of Association or b) any shareholder who holds shares which give him/her the appointment right - those shares may be transferred to another person only if the company gives the consent

${ }^{36}$ Par. 272 c. and 256 Croatian Companies Act
} 
situation, the members of the Board may be elected by the Court, ${ }^{37}$ and in accordance with The Labour Law Act, one member of the Board shall be elected by the employees..$^{38}$ General Meeting of Shareholders is entitled to remove directors from the Board at any time, without a particular reason. ${ }^{39}$ This indicates that in One-Tier System directors are not truly independent; hence they are expected to be removed from the Board if they do not follow shareholders' instructions. This is the main reason why we believe that it is not appropriate to allow founders of the public limited liability companies to choose between One and Two-Tier System of corporate governance. Namely, rules of law regulating governance in public limited liability companies are mandatory - in order to constrain the person who is in control over the company to adjust the governing rules to him and his personal interest. If the legislator allows company (i.e. in practice - the person who is in control of the company) to select between One-Tier and Two-Tier System, that means that person who is in control would be able to apply the system of governance most appropriate for his/her personal interest - and this is exactly what Company Law in general, and Corporate Governance law rules especially, struggle against! If a majority shareholder (who usually holds enough shares to alter the articles of association without consent of minority shareholders) decides to apply OneTier instead of Two-Tier System, he would be able to control not just General Meetings' decisions (as he holds enough shares to take decisions alone) but also the Board of Directors' decisions, as he would be able (through General Meeting of Shareholders) to elect directors and to remove any of them who didn't follow his instructions. ${ }^{40}$ While in most other countries, when One-Tier System is applied, ordinary General Meeting's resolution is enough to remove director from the Board, ${ }^{41}$ under The Croatian Companies Act qualified majority of $3 / 4$ given votes is required. ${ }^{42}$ Thus, majority shareholder will need consent of minority shareholders to remove director from the Board, if he does not hold more than $75 \%$ of shares. It's also interesting to notice that under the Croatian Companies Act, in an exceptional situation, the Court is entitled to remove directors from the Board - if shareholder who possesses more than 1/10 of shares, or if the Board of directors, asked the Court to do so. ${ }^{43}$ Nevertheless, when the Court is to decide whether to remove a certain director or not, it may remove him only if there is a particular reason. Anyway, if Two-Tier System is applied, the opportunity to ask the Court to remove director (no matter whether there is a particular reason or not) does not exist at all - hence, this also illustrates the less independent position directors have in One-Tier than in Two-Tier System.

In Continental-Roman Legal System Countries, where One-Tier System is typical system of corporate governance, hence shareholding structure is dispersed in the most companies; General Meeting of Shareholders is entitled to elect members of the Board of Directors and to remove

\footnotetext{
${ }^{37}$ Par. 272 d. Croatian Companies Act

${ }^{38}$ Par 272 b. Croatian Companies Act and par. 163 The Labour Law Act (NN 149/09, 61/11, 82/12, 73/13)

39 Par. 272 e. and 259 Croatian Companies Act

40 See: Maurović, GonanBožac, Grgorinić, “The One-Tier System,” 8: „Since it is expected that One-Tier System will be implemented in companies with majority shareholders, it is disputable how minority shareholders and other stakeholders will be protected from impact of over-powerful majority shareholders";

For example, in Croatia, "Arenaturistd.d." was the first company to switch on One-Tier System. Even the member of Board of Directors in one occasion has stated for local News Paper ("Glaslstre" - 8.8.2008.) that the company has switched to One-Tier System in order to ensure direct impact of majority shareholder on running a business.

${ }^{41}$ UK: par. 168 Companies Act; FYR Macedonia: par.363/1Companies Act

${ }^{42}$ Par. 272 e. and 259 Croatian Companies Act

${ }^{43}$ Par. 272 e. and 260 Croatian Companies Act
} 
them at any time without a particular reason. ${ }^{44}$

\section{ii. Election and Revocation of Directors in Two-Tier System of Corporate Governance}

Two-Tier System is typical system of corporate governance in Continental-German Legal System Countries. In Germany and Austria it is mandatory system of corporate governance, whilst in Croatia and Slovenia it is possible to apply One-Tier System, ${ }^{45}$ although, the number of companies that apply Two-Tier System exceed by far the number of companies that apply One-Tier System, ${ }^{46}$ probably because the former system has been traditionally used. In Two-Tier System, directors (members of the Managing Board - hereinafter: MB) are not elected directly by General Meeting of Shareholders. Instead, an independent body - the Supervisory Board (hereinafter: SB) is entitled (by the mandatory law rules) to elect the members of the MB. The function of SB is to supervise the activities of $M B$ and to take care that those activities are being undertaken in the best interest of the company as a whole. Moreover, SB should constrain every impact of majority (or controlling) shareholders on directors in order to prevent directors to act in the interest of majority (controlling) shareholders instead in the interest of the company as a whole. If we consider that the General Meeting of Shareholders is entitled to elect and to remove the members of SB, it is hard to believe that $S B$ is absolutely independent when it elects members of MB. Namely, if members of SB have elected a director who does not fit to majority shareholder's preferences, they would probably be removed from SB. On the other hand, it is expected from SB to elect as a director a person who is capable of running a business, otherwise - if SB elected as a director a person who is incapable to run a business, and if during the election SB members did not apply prescribed due diligence, they might be liable for damages incurred by incapable directors. It is important to highlight that the right to elect members of MB is exclusively SB's right, conferred upon SB by mandatory law provisions -therefore, it may not be vested upon other company's body or upon other person. ${ }^{47}$

The independent position of directors (MB members) in Continental-German Legal Systems (such as in Germany, Austria, Slovenia, Croatia) seems to be the most obvious if we consider that they may not be removed from the Board without a particular reason - for example: breach of their duties under the gross negligence, incapacity for work, General Meeting's distrust in their performance etc. ${ }^{48}$ Moreover, if a director believes that he was removed from his duty without a sufficient reason, he may appeal to the Court in order to determine whether there was a sufficient reason or not. It's on the company to prove before the Court that the valid reason existed. If the company does not manage to prove, before the court, that the reason for removal of director was valid, the Company would be liable for compensation of incurred damages. As a consequence,

\footnotetext{
${ }^{44}$ Switzerland: par. 276/1 Swiss Federal Code of Obligations; Spain: par. 13 Stock Corporations Act; France - L. 225 - 18/2 Commercial Code Moreover, in Slovenia, one of the first companies that switched to One-Tier System was "Mobitel" - the Company which is $100 \%$ owned by its parent company "Telekomd.d." - see more in: GrigoryDruzhininet al.,"The Type of Corporate Governance and Employee Outcomes - The case of Slovenia" (Research design, University of Ljubljana - Faculty of Economics, 2008): 3.

${ }^{45}$ In Croatia since 2008, in Slovenia since 2007

${ }^{46}$ In Croatia, just few companies have switched to One-Tier System, for example: "Arenaturist".In Slovenia, about 20 companies implemented One-Tier System, for example: "Mobitel”, “Kompas", “Cestnopodjetje Ljubljana” etc.

${ }^{47}$ Only under exceptional circumstances, MB members may be elected by The Court's decision. See, for example, Croatian Companies Act, par. 245

${ }^{48}$ See: Croatia: par. 244/2 Companies Act; Germany: par. 84/3 AktG; Austria: par. 75/4 AktG; Slovenia: par. 268/2 Companies Act // On the other hand, only in FYR Macedonia SB is entitled to remove directors from MB in any time without a particular reason - par. 363/4 Companies Act
} 
company would be able to sue members of SB for compensation of incurred damages, as they decided to remove director, although no valid reason existed. Therefore, it is understandable why members of SB rather not remove directors from the MB; they are concerned with the fact that they might be liable for (possible) incurred damages if Court will decide that sufficient reason for director removal didn't exist. The right to remove directors from MB is exclusively SB's right. Hence, it may not be vested upon other company's body or upon other person.

\section{Directors' Liability}

The basis of Board members' liability is to be found in the Companies Act. Meanwhile, ground for liability can also be found in numerous provisions of other legal Acts, such as the Bankruptcy Act and Laws regarding companies' bookkeeping and employment protection. Under the Companies Act, Board members do not incur personal liability when they are acting on behalf of the company. The commitments they enter into on behalf of the company directly bind the company, but they will be liable for loss suffered by the company through mismanagement. For the company's mismanagement, third parties will be entitled to initiate proceedings against the Board members. As a rule, this liability requires proof of mismanagement, loss and a causal link between the mismanagement and the loss. The examples of mismanagement are listed under national laws, but the lists do not exclude the possibility to prove (before the Court) another examples of mismanagement.

The EU law regarding directors' liability towards the company, shareholders and thirds as a contract parties, is rather undeveloped. The EU has accepted framework for Board members' joint liability for financial and non-financial information about the company. Accordingly, Member States must insure that Board members are joint liable at least towards the company. That will enable the minimum standardization (in EU Member States) of appropriate sanctions and civil liability for preparing annual reports. The Commission does not suggest Board members' direct liability towards third parties or stronger penalty system.

In every (relevant) legal system - no matter whether it provides just One-Tier or just TwoTier System of Corporate Governance, or both of them - directors are obliged to run a business in a good faith i.e., in accordance with fiduciary duties of care and loyalty, in the best interest of the company. If they fail to act in accordance with respective standards, they are liable for incurred damages. Whether directors are going to be exempted from their duty to compensate incurred damages, primary depends on court's decision. In countries where courts accept directors' exculpation arguments too easily (for example, when they state that they used to act in accordance with the Business Judgment Rule), the prescribed standards are not sufficient measure to constrain directors' opportunistical behavior. For example, Croatian Courts, in numerous cases, have failed to convict inappropriate and unlawful directors' conducts, under the statement that directors were acting in accordance with the duty of care..$^{49}$ Authors believe that Croatian judicial practice is going to be revised under the influence of recently declared (2012) Act on Financial Operations and Pre-Bankruptcy Settlement, ${ }^{50}$ which in details prescribes how directors should act in certain situations, especially in the cases of illiquidity or insolvency threats. ${ }^{51}$ Since respective Act entered

\footnotetext{
49 See: Croatian High Commercial Court - Pžz-5968/05, 17. September 2008.

For more Cases, see: JasenkaPavišićČačić and NikolinaMišković, "Civil Liability of Members of The Management Board in Judicial Practice," in Financing, Governance and Companies' Restructuring in the Age of Recession, ed. EditaČulinovićHerc et al. (Rijeka: University of Rijeka Law School Press, 2011), 181-183.

${ }^{50}$ Act on Financial Operations and Pre-Bankruptcy Settlement (NN 108/12, 144/12, 81/13)

${ }^{51}$ Par. 5, 7-10 Act on Financial Operations and Pre-Bankruptcy Settlement
} 
into force, Courts are obliged just to determine whether directors used to act in accordance with mandatory provisions regulating their duties or not, and therefore, if they have failed to do so, they should be liable for compensation of incurred damages, thus - there is no possibility to ask for exculpation on the Business Judgment Rule grounds.

Judicial enforcement of provisions regulating the liability of directors is the most adequate measure for combating the Agency Problem and reducing Agency Costs..$^{52}$ Considering that provisions regulating the liability of directors should be applied on controlling shareholders - whenever they have induced directors to act improperly, conclusion is that the same measure is equally appropriate for reducing the Agency Problem on the second level i.e., between controlling and non-controlling shareholders.

\footnotetext{
${ }^{52}$ When directors are aware that they might be liable for incurred damages if they do not run a business withdue diligence in the best interest of the company as a whole, they are more likely to act in accordance with their duties. We may conclude that judicial enforcement of provisions regulating directors' liabilityis not just a repressive measure. It is also a preventive measure - as it prevents directors from unlawful and disloyal conduct.
} 


\section{CONCLUSION}

Agency Problem (or Principal-Agent Problem) is the term usually used by economists to describe several conflicts of interest immanent for corporate governance. Traditionally, in every (relevant) legal system, one system of corporate governance (One-Tier or Two-Tier) was prescribed by the law as a mandatory one. Two-Tier System is set to reduce the conflict of interest between majority and minority shareholders (or in economic terms - to reduce the second type of P-A problem). Therefore, it used to be a mandatory system of corporate governance in every country where concentrated shareholding was typical shareholding pattern. On the other hand, One-Tier System is set to reduce the conflict of interest between directors and shareholders (or in economic terms - to reduce the first type of P-A problem) - thus, it used to be a mandatory system of corporate governance in countries where companies with dispersed shareholders dominated. Legislators used to prescribe only one system of corporate governance as a mandatory one in order to ensure good corporate governance, i.e. to constrain the person who is in control over the company from applying the system of governance which will enable him/her to use the company for achieving his/ her personal interest. Nevertheless, providing only one system of corporate governance as a mandatory one, may be a counterproductive measure. Namely, in every country, although dispersed or concentrated shareholding dominates, it is still possible to form a company with "unusual" shareholding structure. Consequently, if there is no possibility to select the appropriate system of governance, Agency Problems are likely to multiply in every company with "unusual" shareholding structure.

We may conclude that neither of two analyzed systems of Corporate Governance is better than the other one, per se. Which system would be more appropriate for reducing the conflict of interest between parties involved in corporate governance (or for reducing the Agency Problem as economists prefer to say), depends on certain circumstances - such as; who owns control over the company, etc. Implementing the system appropriate to reduce the Agency Problem would consequently reduce Agency Costs, as it would constrain agents to behave opportunistically.

Numerous European countries, influenced by Regulation on the Statute for a European Company (SE) - which provides opportunity to select between One-Tier and Two-Tier System of Governance when founding European Company (SE), have introduced the same possibility under the national Company Law system. Conferring upon shareholders (founders of the company) the right of choice between One-Tier and Two-Tier System is not appropriate measure for reducing Agency Problem. Adversely, it is a measure which may lead to multiplication of Agency Costs - if founders apply inappropriate system of corporate governance. Accordingly, if majority shareholder decided to apply One-Tier System, he would have absolute control over the company, hence he would be able to take decisions on General Meeting of Shareholders without consent of minorities, plus he would have direct control over directors - as he would be able to elect them and to remove them at any time if he is not satisfied with their work. Likewise, if in companies with dispersed shareholding, directors somehow induce shareholders to accept Two-Tier System, it will be even more difficult for shareholders to control directors - thus, they would get chance to act more opportunistically.

Consequently, we conclude that it should be prescribed that system of corporate governance depends on shareholding structure in particular company. Accordingly, if the structure of shareholders alters, the system of corporate governance should be altered too. This may be prescribed under the law (for example, under the Companies Act), but it should be applicable only on listed companies. In this way, founders of "closed" or "family-business" companies (which are not listed on stock-market) would not be restricted in selecting the system of corporate governance 
which is the most appropriate for them.

Moreover, the recommendation to select a proper system of corporate governance (in accordance with shareholding structure) may be prescribed by Codes of Corporate Governance. ${ }^{53}$ Namely, provisions of these Codes apply only on listed companies. Those provisions are not mandatory, but if they are not applied it must be explained why (comply or explain system). "By implementing Codes' Principles corporations may attract or retain quality investors, creditors and employees and achieve the final business goal: to create a long-term value to the shareholders by taking into account the interest of all shareholders. ${ }^{154}$ Therefore, if in particular listed company the Code's provisions are not applied, this indicates that in a respective company the best practice of corporate governance is not introduced. Accordingly, that should be a considerable indication for every potential investor to not invest in a respective company.

\footnotetext{
${ }^{53}$ In order to examine whether similar provisions already exist in Codes of Corporate Governance applicable in Countries where is possible to establish the company with One-Tier or with Two-Tier System of Corporate Governance, the authors of this paper have analyzed several Codes of Corporate Governance: Croatian CCG (http://zse.hr/default.aspx?id=10865), Slovenian CCG (http://www.ljse.si/media/Attachments/English/Statistika/Kodeks07.pdf), FYR Macedonian CCG (http:// www.ebrd.com/downloads/legal/corporate/macedon_code.pdf), Italian CCG (http://www.borsaitaliana.it/borsaitaliana/ regolamenti/corporategovernance/corporategovdec2011.en_pdf.htm), French CCG (http://www.ecgi.org/codes/ documents/cg_oct03_en.pdf), Portuguese CCG (http://www.ecgi.org/codes/documents/cg_code_cnmv_sept2007_ en.pdf), Dutch CCG (http://www.dsm.com/content/dam/dsm/cworld/en_US/documents/corporate-governancecode-en.pdf), Iceland CCG (http://www.ecgi.org/codes/documents/iceland_2009_en.pdf) and Lithuanian CCG (http:// www.nasdaqomxbaltic.com/files/vilnius/teisesaktai/The\%20Corporate\%20Governance $\% 20$ Code $\% 20$ for $\% 20$ the $\% 20$ Companies\%20Listed\%20on\%20NASDAQ\%20OMX\%20Vilnius.pdf), and they didn't manage to find neither one provision recommending that the choice between One-Tier and Two-Tier Systemshould be done in accordance with certain criteria. ${ }^{54}$ LjiljanaMaurovićand Sabina Grgorinić, "The Place of Codes of Corporate Governance in The EU Company Law"(paper presented at the 7th International Conference «Economic Integration, Competition and Cooperation», Opatija, Croatia, April 2-3, 2009): 2, available at: http://papers.ssrn.com/sol3/papers.cfm?abstract_id=2236894
} 


\section{BIBLIOGRAPHY}

Armour, John; Hansmann, Henry and Kraakman, Reinier. "Agency Problems, Legal Strategies and Enforcement," Harvard - John M. Olin Center for Law, Economics and Business, Discussion Paper, 644 (2009): 1-17, available at: http://www.law.harvard.edu/programs/olin_center/

Davies, Paul L. Gower and Davies' Principles of Modern Company Law - ninth edition. London: Sweet \& Maxwell, 2012.

Davies, Paul L. "The Board of Directors: Composition, Structure, Duties and Powers." Paper presented at Conference on Company Law Reform in OECD Countries: A Comparative Outlook of Current Trends, Stockhlom, Sweeden, December 7-8, 2000., available at: http://www.oecd.org/daf/ $\mathrm{ca} /$ corporategovernanceprinciples/1857291.pdf

Druzhinin, Grigory; Erjavec, Vanja; Leskovec, Darja; Santini, Luciano; Senčar, Miha. "The Type of Corporate Governance and Employee Outcomes - The case of Slovenia." Research design, University of Ljubljana - Faculty of Economics, 2008.

Girvin, Stephen; Hudson, Alastair and Frisby, Sandra, ed. Charlesworth's Company Law - 18th edition. London: Sweet and Maxwell, 1996.

Jensen, Mihael C. and Meckling, Wiliam H. "Theory of the Firm: Managerial Behaviour, Agency Costs and Ownership Structure." Journal of Financial Economics, 3 (1976): 305 - 360, available at: http://ssrn.com/abstract $=94043$

Löbbe, Marc. "Corporate Groups: Competences of the shareholders' meeting and minority protection - the BGH's recent Gelatine and Macrotron cases redefine the Holzmüller doctrine." German Law Journal, 5 (2004): 1058-1079, available at: http://www.germanlawjournal.com/pdfs/ Vol05No09/PDF_Vol_05_No_09_1057-1079_Private_Loebbe.pdf;

Maurović, Ljiljana, Gonan Božac, Marli and Lacmanović, Sabina. "The One-Tier System on Corporate Governance - Croatian Practice." Economic Research 22 (2009): 114 - 126, available at: http://hrcak.srce.hr/38201

Maurović, Ljiljana and Grgorinić, Sabina. "The Place of Codes of Corporate Governance in the EU Company Law." Paper presented at the 7th International Conference «Economic Integration, Competition and Cooperation», Opatija, Croatia, April 2-3, 2009; available at: http://papers. ssrn.com/sol3/papers.cfm?abstract_id=2236894

Pavišić Čačić, Jasenka and Mišković, Nikolina. "Civil Liability of Members of the Management Board in Judicial Practice." In Financing, Governance and Companies' Restructuring in the Age of Recession, edited by Edita Čulinović Herc, Dionis Jurić, and Nataša Žunić Kovačević, 157 - 185. Rijeka: University of Rijeka Law School Press, 2011.

Schult, Ludger and Nikoleyczik, Tobias. "Shareholder approval for corporate acquisitions - the Commerzbank/Dresdner Bank case." Corporate and M\&A Law Newsleter, September (2012): 35-36, available at: http://www.glns.de/fileadmin/user_upload/dokumente/IBA_M_A_Newsletter.pdf 